\title{
Antibacterial immune functions of subadults and adults in a semelparous spider
}

\author{
Zoltán Rádai ${ }^{\text {Corresp., } 1}{ }^{\text {, Péter Kiss }}{ }^{1}$, Dávid Nagy ${ }^{1}$, Zoltán Barta ${ }^{1}$ \\ 1 MTA-DE Behavioural Ecology Research Group, Department of Evolutionary Zoology, University of Debrecen, Debrecen, Hungary \\ Corresponding Author: Zoltán Rádai \\ Email address: radai.zoltan@science.unideb.hu
}

Although capacity to mount an efficient immune response plays a critical role in individuals' survival, its dynamics across ontogenetic stages is still largely unexplored. Life stage-dependent variation in the encountered diversity and prevalence of parasites were proposed to contribute to stage-dependent changes in immunity, but differences in life history objectives between developmental stages may also lead to stage-specific changes in efficiency of given immune mechanisms. The reason for this is that juveniles and subadults are unable to reproduce, therefore they invest resources mainly into survival, while adults have to partition their resources between survival and reproduction. The general trade-off between somatic maintenance and reproductive effort is expected to impair immune function. Especially so in semelparous organisms that only reproduce once throughout their lifetime, hence they do not face the trade-off between current and future reproduction. We hypothesized that in a semelparous species individuals would be characterized by decreased investment into somatic maintenance after maturation, in order to maximise their reproductive output. Accordingly, we predicted that (1) elements of somatic maintenance, such as immunity, should be relatively weaker in adults in comparison to subadults, and (2) increased reproductive investment in adults should be associated with lower immune efficiency. We quantified two markers of immunity in subadult and adult individuals of the semelparous wolf spider Pardosa agrestis (Westring, 1861), namely bacterial growth inhibition power and bacterial cell wall lytic activity. We found that subadults showed significantly higher cell wall lytic activity than adults, but the two life stages did not differ in their capacity to inhibit bacterial growth. Also, we found weaker immune measures in mated females compared to virgins. Furthermore, in mated females bacterial growth inhibition power was negatively associated with fecundity. 
1 Antibacterial immune functions of subadults and adults in a semelparous spider

2

3 Zoltán Rádai ${ }^{1}$, Péter Kiss ${ }^{1}$, Dávid Nagy ${ }^{1}$, Zoltán Barta ${ }^{1}$

$4{ }^{1}$ MTA-DE Behavioural Ecology Research Group, Department of Evolutionary Zoology,

5 University of Debrecen, Debrecen, Hungary

6

7 Corresponding Author:

8 Zoltán Rádai

9 Egyetem tér 1. Debrecen, 4032, Hungary

Email address: radai.zoltan@science.unideb.hu

\begin{abstract}
Although capacity to mount an efficient immune response plays a critical role in individuals' survival, its dynamics across ontogenetic stages is still largely unexplored. Life stage-dependent variation in the encountered diversity and prevalence of parasites were proposed to contribute to stage-dependent changes in immunity, but differences in life history objectives between developmental stages may also lead to stage-specific changes in efficiency of given immune mechanisms. The reason for this is that juveniles and subadults are unable to reproduce, therefore they invest resources mainly into survival, while adults have to partition their resources between survival and reproduction. The general trade-off between somatic maintenance and reproductive effort is expected to impair immune function. Especially so in semelparous organisms that only reproduce once throughout their lifetime, hence they do not face the trade-off between current and future reproduction. We hypothesized that in a semelparous species individuals would be characterized by decreased investment into somatic maintenance after maturation, in order to maximise their reproductive output. Accordingly, we predicted that (1) elements of somatic maintenance, such as immunity, should be relatively weaker in adults in comparison to subadults, and (2) increased reproductive investment in adults should be associated with lower immune efficiency. We quantified two markers of immunity in subadult and adult individuals of the semelparous wolf spider Pardosa agrestis (Westring, 1861), namely bacterial growth inhibition power and bacterial cell wall lytic activity. We found that subadults showed significantly higher cell wall lytic activity than adults, but the two life stages did not differ in their capacity to inhibit bacterial growth. Also, we found weaker immune measures in mated
\end{abstract}


33 females compared to virgins. Furthermore, in mated females bacterial growth inhibition power 34 was negatively associated with fecundity.

35

36 


\section{Introduction}

38 The capacity to effectively respond to antigens to minimize fitness costs of infection (Owens \&

39 Wilson, 1999) is a critically important element of somatic maintenance. Although its efficiency

40 is highly correlated with fitness (Rolff 2002; Viney et al., 2005), considerable variation persists

41 in the efficacy of immune functions in natural populations (Brinkhof et al., 1999; Norris \&

42 Evans, 2000; Calsbeek et al., 2008). In the last two decades, immunoecology aimed at shedding

43 light on the causes and consequences of such diversity. Until recently numerous studies were

44 carried out in this subject (reviewed in: Sheldon \& Verhulst, 1996; e.g. Lochmiller \&

45 Deerenberg, 2000; Harshman \& Zera, 2007; Cotter et al., 2008; Sadd \& Schmid-Hempel, 2009;

46 Crino et al., 2013; Palacios et al., 2013; Park \& Stanley, 2015), mainly focusing on the

47 variability of adult immunocompetence, and the effects of juvenile-experiences (such as

48 immune-challenge or nutritional deficiency) on adult immunocompetence (Norris \& Evans,

49 2000; Ricklefs \& Wikelski, 2002; Jacot et al., 2005; Stoehr \& Kokko, 2006; Martin et al., 2007;

50 DeBlock \& Stoks, 2008; Kriengwatana et al., 2013; Gilbert et al., 2016). However, still

51 surprisingly little is known about how the baseline efficiency of the immune system changes

52 through the different life stages.

53 Differences in the type or density of pathogens individuals might encounter throughout their life 54 cycle were proposed to contribute to across-stage differences in immune function (Wilson-Rich et al., 2008; Shi \& Sun, 2010). Also, expected reproductive value of different life history actions may change with the progression of ontogeny (e.g. investment in reproduction might be more valuable in mature than in immature individuals), so optimal investment into somatic maintenance, and hence into immunity, might also show stage-specific changes (Shi \& Sun, 2010; Giglio \& Giulianini, 2013). Indeed, juveniles and subadults can't reproduce, therefore they would be expected to invest resources mainly into somatic maintenance, while adults have to partition their resources between maintenance (and hence survival) and reproduction.

Stage-specific characteristics of organisms' life histories can strongly depend on their reproductive strategies. In semelparous organisms, individuals have only one chance to reproduce during their lifetime, and hence cannot trade off between current and future reproduction. Consequently, after maturation they would be expected to prioritise reproduction over somatic maintenance during the production of costly gametes, which starts shortly after maturation. We expect to see this prioritization to be pronounced in semelparous species, 
68 because the production of gametes in sufficient amount (and quality) shortly after maturation has

69 critical impact on lifetime reproductive success, as there will be no future reproductions during

which an individual might increase its lifetime reproductive success. In such a scenario, we would expect to see that individuals of a semelparous species invest less into somatic maintenance (and hence into costly elements of immunity as well) in adulthood relative to the somatic maintenance during preadult development.

In this study we evaluated two proxies of immune capacity in subadult and adult individuals of the wolf spider Pardosa agrestis (Westring, 1861), and quantified reproductive investment of females using the number of their offspring. Individuals of $P$. agrestis mature and reproduce during spring and early summer, and offspring either overwinter and reproduce in the next year, or during late summer and autumn, i.e. there are two separate adult peaks throughout the year (Kiss \& Samu, 2005; Rádai et al., 2017a). In general, gamete production starts shortly after maturation in spider females (Foelix, 2011). Although little is known about sperm production in males, generally males also start gamete production shortly after the final moulting, and sperm is then excreted and stored in the pedipalps until mating. Adults reproduce shortly after maturation, not long after which males perish. Females usually lay one to three cocoons after mating, and carry the hatched spiderlings for a short period of time, then also perish. We chose $P$. agrestis as our model organism because it is a quite abundant semelparous spider in Europe, and is relatively easy to collect and study in laboratory (Rádai et al., 2017b, 2018a). This semelparous spider species, by definition, reproduces once during its lifetime (Kiss, 2003). Therefore, based on the argument outlined above, one would expect individuals after maturation to invest less in somatic maintenance compared to premature individuals.

For proxies of immunocompetence we measured the efficiency of bacterial growth inhibition and cell wall lytic activity of tissue homogenates prepared from the spiders' abdomens. In the bacterial growth inhibition assay the availability of antimicrobial peptides is assessed, which are released in the presence of bacteria or fungi at the site of infection, as part of the spiders' humoral immune response (Gao et al., 2005). These molecules mainly compromise the integrity of cell wall and cell membrane of the invading microbes (Brogden, 2005). Antimicrobial peptides are usually stored in granulocytes (specialised hemocytes), which are produced in the heart wall, from prohemocytes, but can be found in fat bodies as well (Kuhn-Nentwig \& Nentwig, 2013). Lytic activity of lysozymes, is also important part of the humoral immune response. Being 
99 glycoside hydrolases, lysozymes conduct the lysis of the peptidoglycans in the bacterial cell wall

100 (Sharon, 1967). Although it is unknown where lysozymes are produced and stored in spiders, the

101 hemolymph contains them in considerable quantities (Ahtiainen et al., 2005). Therefore the

102 homogenate sample of the spider abdomen is likely adequate to assess lysozyme activity, as the

103 largest hemolymph vessel (i.e. heart) in the spiders' body is located in the abdomen. Because

104 these biomolecules are not only produced during infection but are also present in the hemolymph

105 and some cells of healthy individuals, measuring the growth inhibition and lytic activity of

106 samples (which are proportional to the concentrations of corresponding molecules in the sample,

107 see Castella et al., 2010) informs us about the amount of the deployable molecules, and hence the

108 level of investment into the maintenance of these immune functions (McKean \& Lazzaro, 2011).

109 Although bacterial growth inhibition assay and lytic activity assay assess similar immunological

110 functions (e.g. disruption of the cell wall integrity and production of bacteria), bacterial growth

111 inhibition is a result of the effect of several types of peptides, with various mechanisms acting on

112 a wide range of microbes, i.e. are expected to be effective against microbes in general when

113 released simultaneously. Indeed, a number of bactericide and fungicide antimicrobial peptides

114 were identified in arachnids, which collectively are thought to be efficient in the elimination of a

115 wide range of microbes (see Bednaski et al., 2015). Notably, lytic activity strictly assesses the

116 activity and availability of lysozymes, i.e. a type of enzymes with the sole function of disrupting

117 the cell wall of Gram positive bacteria. Therefore, the former assay represents a more general

118 assay on the potential capacity to prevent (or halt) microbial invasion, whereas the latter informs

119 about the potential capacity to neutralise Gram positive bacteria susceptible to lytic enzymes.

120 Using the above described assays we investigated whether subadult and adult individuals of $P$.

121 agrestis differ in the bacterial growth inhibition power and cell wall lytic activity, i.e. in the

122 maintained capacity to mount either a complex, or a simpler, immediate immune response

123 against microbial infection. For these tests we used males and females as well, in order to see

124 whether the costs of maturation interfere with adult immunity in both sexes. Sexes might differ

125 in how they trade off key life history traits due to their differences in the ways they can maximise

126 reproductive output (Lawniczak et al., 2007; Vincent \& Gwynne, 2014). Additionally, in females

127 collected from natural habitats we assessed how reproductive status (whether a female was virgin

128 or not) and fecundity (number of offspring) were associated with the immune parameters we

129 used. We predicted to see stronger immune parameters in subadult specimens, and expected 
130 mating and egg laying to negatively affect the tested females' immune measures. Similarly, due

131 to the energetic trade-offs between somatic maintenance and reproduction, we expected to see

132 negative associations between fecundity and the immune parameters.

\section{Materials and methods}

134 Spiders

135 We collected spiders on three occasions. Firstly, we have established a laboratory-reared

136 population, in which specimens originated from nine cocoon carrying females. These females

137 were collected in May of 2016, from two closely located habitats: an uncultivated plot next to a

138 maize field (between Hajdúszoboszló and Nádudvar, Hungary; 47²6'56.3"N 21 ${ }^{\circ} 18^{\prime} 00.2^{\prime \prime E}$ ), and

139 the edge of a maize field (between Hajdúszoboszló and Nagyhegyes, Hungary; 47²8'31.2"N

$14021^{\circ} 21^{\prime} 57.3^{\prime \prime E}$ ). These habitats were quite close to one another (ca. $5 \mathrm{~km}$ linear distance),

141 established on an alluvial plain (i.e. with minimal differences were expected in habitat

142 characteristics). After spiderlings hatched in May and June, we separated 58 specimens, and

143 placed each of them separately in plastic cups with a floor area of approx. $25.5 \mathrm{~cm}^{2}$. Spiderlings

144 were provided water (wet cotton wool) and food (springtails for the first few moults, then fruit

145 flies for larger spiders) ad libitum. Cups were checked for exuvia (i.e. moulting) every two days,

146 and the dates of hatching and moulting were recorded for each spider. Spiders were reared until

147 December, 2016. Prior to the preparation of samples, each spider was categorised to be either as

148 subadult (undeveloped, but recognizable genitals; observed in penultimate specimens one moult

149 prior to maturation), or as adult (fully developed genitals). Henceforth, we refer to spiders that

150 were one moult prior to maturation (i.e. penultimate) as "subadult". We chose to work with

151 subadults rather than juvenile instar larvae because the small sizes of juveniles makes it rather

152 difficult to use the established methods reliably. Following the rearing period, we were able to

153 work with 38 spiders, of which 27 were subadults (11 females and 16 males) and 11 were adults

154 (7 females and 4 males). All laboratory reared spiders used in the immune assays were virgins.

155 Secondly, we have collected subadult females and adult cocoon carrying females at spring and

156 late summer in 2017 from the habitats described above. Subadult females were reared until

157 maturity in laboratory. This way we had virgin and mated females as well for our tests. In total

158 we were able to work with 154 females, among which there were 37 virgin and 66 mated females

159 from spring, and 23 virgin and 28 mated females from late summer. Because some of the 
160 cocoons from the mated females either enveloped dead embryos, were parasitized by Idris

161 flavicornis (Hymenoptera: Scelionidae) wasps (see Rádai et al., 2018b), or were used for other

162 tests, we had fecundity data from 25 spring and 28 late summer females.

\section{Sample preparation}

164 Laboratory-reared spiders were used for sample preparation in December, 2016. Females

165 collected from natural habitats were used for sample preparation in May and August, 2017 in the

166 case of spring and late summer females, respectively.

167 Bacterial growth inhibition capacity and cell wall lytic activity assays were carried out according 168 to Castella et al. (2010). For both methods the samples were prepared as follows. Spiders were

169 killed at $-20^{\circ} \mathrm{C}$. The abdomen of the spiders was separated from the prosoma by cutting the

170 pedicel. We decided to use full abdomens because the heart and fat bodies, which are known to

171 have central role in the production of immune cells, can be found in the abdomen. Also, a large

172 portion of hemolymph resides in the abdomen, that contains immune cells and lysozyme.

173 Furthermore, the lung-openings and intestines are also found in the abdomen, which comprise a

174 considerable contact surface for potential microbial invasion, so it would be expected that

175 immune parameters of neighbouring tissues faithfully represent the spiders' readiness to keep

176 microbes at bay.

177 Abdomens were homogenised on ice, in $50 \mu \mathrm{PBS}\left(\mathrm{ca} .4^{\circ} \mathrm{C}\right.$ ), and stored on ice until

178 centrifugation. Centrifugation was carried out at $10000 \mathrm{~g}$, at $4^{\circ} \mathrm{C}$ for 10 minutes. After

179 centrifugation, $20 \mu \mathrm{l}$ from the supernatant per sample were collected separately for bacterial

180 growth inhibition and cell wall lytic activity tests, then stored at $-20^{\circ} \mathrm{C}$ until measurements.

181 Prosomas were stored in $96 \%$ ethanol on $-20^{\circ} \mathrm{C}$ for later size measurements, which was done

182 with the prosomas photographed on millimeter graph paper, then measuring with ImageJ

183 (version 1.46a, Schneider, Rasband, \& Eliceiri, 2012).

184 Samples from 2016 were tested in January, 2017, and samples from 2017 were tested in

185 December, 2018. During the bacterial growth inhibition tests we always used freshly cultured

186 bacteria (see below) from the same laboratory strain. Also, in the cell wall lysis tests we used the 187 same type of commercially available cell wall residues (see below) in both test sessions. 
189 We applied $2 \mu \mathrm{l}$ from each tissue homogenate sample on the surface of a thin layer of agar-based 190 medium (using $6 \mathrm{ml}$ of agar in each petri dish), in duplicates from each spider. Duplicates were 191 placed in the same petri dish in the case of all samples, and in one petri dish 10 samples (i.e. 5

192 duplicates) were applied. The medium contained $1 \mathrm{~g}$ of bacto-tryptone, $1 \mathrm{~g} \mathrm{NaCl}, 0.5 \mathrm{~g}$ yeast 193 extract and $1 \mathrm{~g}$ agar in $100 \mathrm{ml}$ distilled water. Also, prior to pouring the agar into petri dishes, 50 $194 \mu \mathrm{l}$ from a $2.6 \times 10^{8}$ cells ml-1 ${ }^{-1}$ suspension of Micrococcus luteus (obtained from Tamás Emri’s lab 195 culture at the Department of Microbial Biotechnology, University of Debrecen) was added and 196 mixed carefully. We used M. luteus because of its availability, and because it is frequently 197 present in soil (Biskupiak et al., 1988; Sims, Sommers, \& Konopka, 1986); as P. agrestis is an 198 epigeic species, it is expected to frequently encounter M. luteus straints. Petri dishes with the samples applied were incubated at $30^{\circ} \mathrm{C}$ for 24 hours. Samples containing antimicrobial peptides inhibit bacterial growth, therefore empty zones (so called inhibition zones) will persistm on the

201

202

203

204

205

206

207

208

209

210

211

212

213

214

215

216

217 218 were measured using ImageJ (see below). bacterial culture where antimicrobial peptide containing samples were applied. The area of inhibition zones is proportional to the antimicrobial peptide content of the samples. Following the incubation, all petri dishes were photographed, and the areas of inhibition zones were measured using ImageJ (see below).

\section{Bacterial cell wall lytic activity assay}

We prepared a simple agar-based medium ( $1 \mathrm{~g}$ agar in $100 \mathrm{ml}$ distilled water) containing $5 \mathrm{mg}$ $\mathrm{ml}^{-1}$ Micrococcus lysodeikticus (lyophilized Micrococcus lysodeikticus, ATCC No. 4698, SigmaAldrich; note that M. lysodeikticus and M. luteus are considered to be the same group of bacteria, e.g. Litman, 1968) cell wall residues homogeneously distributed, and $0.6 \mathrm{mg} \mathrm{ml}^{-1}$ ampicillin sodium. This strain was used because of its commercial availability. The basic principle of this method is that samples containing lysozyme will produce transparent clearing zones in the opaque layer of cell wall containing agar, and the area of clearing zones is proportional to the lysozyme concentration of the sample. We poured $5 \mathrm{ml}$ of this medium in each petri dish and applied $2 \mu \mathrm{l}$ from each sample on the surface of the cell wall agar, in duplicates from each spider. Duplicates were placed in the same petri dish in the case of each sample, and in one petri dish 10 samples (i.e. 5 duplicates) were applied. Petri dishes were then incubated at $30^{\circ} \mathrm{C}$ for 24 hours.

17 Following the incubation, all petri dishes were photographed, and the areas of clearing zones 


\section{Statistical analyses}

220 Statistical analyses were performed using the R statistical software (version 3.0.2, R Core Team, 221 2014).

222 Because the cut-off point of rearing period was the same for all spiders, we checked whether 223 there was a significant difference in the time interval from hatching to sample preparation

224 between subadults and adults, by using Welch's t-test on developmental times (i.e. time from

225 hatching to end of rearing period). A lack of significant difference would imply that spiders had

226 approximately the same time to develop, therefore those specimens that reached maturity had a

227 more rapid somatic development than those that couldn't reach maturity (i.e. remained

228 subadults). Conversely, if adult spiders were characterized by significantly longer developmental

229 time it would mean that they hatched more early and had more time to mature, hence their

230 maturation success during the rearing period is not a direct result of faster development.

231 Additionally, we used Chi-squared $\left(\mathrm{X}^{2}\right)$ test to see if there are significant differences in the

232 number of adults and subadults between mother spiders.

\section{Quantifying bacterial growth inhibition and cell wall lytic power}

234 Bacterial growth inhibition and cell wall lytic capacities were quantified as follows. Measured areas of inhibition- and clearing zones (for bacterial growth inhibition and cell wall lytic activity, respectively) were given in pixel count. Photographing the petri dishes was done at different times, hence on the distance between the camera and the petri dishes varied slightly between images. In order to render inhibition / clearing zone values comparable between petri dishes, we divided their area by the area of the given petri dish (all petri dishes were the same size). This resulted in values representing the relative size of inhibition and clearing zones, proportional to

241 the total area of the given petri dish (hereafter relative zone areas). Relative zone areas were

242 divided by the cube of prosoma width to calculate inhibition- and clearing zones corrected for

243 body volume. As whole abdomens of different sized spiders were homogenized in the same 244 volumes of buffer, the relative zones corrected with the cube of prosoma width estimated the 245 inhibition- and lytic power of samples per $\mathrm{mm}^{3}$ of body volume. In order to aid convergence of 246 model fitting, and interpretation of results after analyses, the variables representing bacterial 247 growth inhibition power and cell wall lytic power (i.e. size-corrected relative zone areas) were 248 centered at zero (by subtracting the mean of the given variable from each value) and rescaled (by 
249 dividing all values by the standard deviation of the given variable). Because the response

250 variables were divided by their standard deviation, regression coefficients coincide with the

251 effect sizes (Cohen's d).

252 Developmental stage differences in immune markers

253 To quantify growth rate we used a variable calculated as dividing the cube of prosoma width by 254 developmental time (i.e. number of days from hatching to the end of rearing). We analysed our 255 data from an animal-model approach (Wilson et al., 2010) using the R-package "MCMCglmm" 256 (Hadfield, 2010), applying a multi-response mixed effects model. We chose this modelling 257 approach because by fitting only one model we are able (a) to estimate regression coefficients 258 (and the coefficients' credibility) for predictor variables on multiple response variables 259 simultaneously, (b) to control for random effects (such as pseudo-replication from repeated measurements) and hence to estimate measurement repeatability, and (c) to estimate coefficients

261 (and their credibility) representing association between the responses, while controlling for a 262 263 number of fixed- and random-effects. In this specific model we used data only from laboratoryreared spiders.

264 The multi-response model was built as follows: bacterial growth inhibition power and cell wall lytic activity were response variables, and, for both response variables, life stage, sex and growth rate were predictors. We did not include interactions between predictors in order to avoid overparameterization. In the model we used the ID number of spiders as random factor to control for repeated measurements, ID of petri dishes to control for between petri dish error, and the ID number of the spiders' mother to control for kinship between spiders. Variance structures of the model were defined to estimate random intercept- and residual covariance between responses. The former reflects the covariation between random intercepts estimated for the responses, practically representing correlation between responses. A positive random intercept covariance indicates that those observations with higher-than-average values in the first response variable

274 tend to have similarly higher-than-average values in the second response. Residual covariance represents the covariation between residuals of the responses. For example, a negative residual covariance might indicate the presence of a trade-off between the two responses, in the sense that

277 those individuals investing too much into one trait will be characterised by lower values in the 278 second response. Note that positive random intercept covariance and negative residual 
279 covariance can occur at the same time, hinting at that good quality specimens are able to invest

280 more-than-average into both responses, but extremely high investment into the first will not

281 enable similarly high investment to the second (e.g. due to the limited nature of used resources;

282 see Hadfield, 2018).

283 The model was run for 115000 iterations (out of which the first 15000 was discarded as "burn-

284 in"), with a thinning interval of 20, resulting in a nominal sample size of 5000 in the posterior

285 distributions. Following model fitting we have estimated the precision of the used methods as the

286 repeatability of the within-individual measurements, by calculating the proportion of between

287 individual variance to the sum of between individual and residual variance. Low values of this

288 measure indicate low precision, while high values indicate reliable measurements of high

289 precision.

290 In the results we report parameter estimates (coefficients) as the modal (most frequent, i.e. most

291 probable) values from the posterior distributions. Also, Bayesian credible intervals are presented

292 as the lower $\left(\mathrm{HPD}_{\text {lower }}\right)$ and upper $\left(\mathrm{HPD}_{\text {upper }}\right)$ cut points of the $95 \%$ highest posterior density

293 intervals.

294 Association between reproductive status, fecundity and immune markers

295 We have fitted a multi-response model, using data from the females collected from the natural

296 habitats in 2017. In this model the response variables were bacterial growth inhibition power and

297 cell wall lytic activity, and predictors were reproductive status (virgin, versus mated), season of

298 collection (spring versus late summer), and the interaction between status and season. We

299 defined ID number of spiders, and ID number of petri dishes as random effects to control for

300 pseudo-replication and between-petri error. Similarly to the above described model, we fitted the

301 model in a manner so that random intercept- and residual covariances were estimated. The model

302 was run for 115000 iterations (out of which the first 15000 was discarded as "burn-in"), with a

303 thinning interval of 20, resulting in a nominal sample size of 5000 in the posterior distributions.

304 Repeatability of immune measurements was calculated the same way as for measurements on

305 laboratory-reared spider samples.

306 To test how efficiency of bacterial growth inhibition and cell wall lytic activity were associated

307 with fecundity in mated females, we fitted a classical (frequentist) linear regression model. In

308 this model fecundity was the response variable, and the assessed immune measures were 
309 predictor variables. We also included season of spider collection as a confounding variable, and

310 its interaction with both immune markers. Because a substantial number of samples produced no

311 measurable inhibition and/or clearing zones, we additionally fitted binomial generalized

312 regression models, in order to test whether fecundity was associated with the probability of

313 producing measurable (i.e. higher than zero) zones. In these models we specified binary variables

314 as responses, indicating whether inhibition zones in bacterial growth inhibition assay, and

315 clearing zones in cell wall lytic assay, were measurable or not. Predictor variables were

316 fecundity, season of collection, and the interaction term between the two. Since in previous

317 models season appeared to affect the response variables in the above described frequentist

318 models, we estimated variance inflation factor (VIF) for the models, using the R-package "fmsb"

319 (Nakazawa, 2018); since in the frequentist models VIF values were low (below 2.5), we assessed

320 that the correlating independent variables do not cause substantial multicollinearity.

321 Additionally, because for each female we had two measurements of the immune markers in the

322 data used by the afore described two frequentist models, but only had one fecundity value, we

323 used the averaged bacterial growth inhibition and cell wall lytic values for each female.

324 In the results of Bayesian models we report $\mathrm{P}_{\mathrm{MCMC}}$-values as the proportion of MCMC samples

325 not crossing zero in the posterior distribution. These values practically represent the probability

326 that (based on the data) the posterior mean of the regression coefficient is zero. Using the $\mathrm{P}_{\mathrm{MCMC}}$

327 values we specified the threshold for significance to be 0.05 . Note that assessment of

328 significance using this threshold coincides with the usage of $95 \%$ credible intervals, i.e.

329 statistical significance can be assessed based on whether the credible intervals include zero. That

330 being said, we decided to still report $\mathrm{P}_{\mathrm{MCMC}}$ values to ease interpretation of results for those not

331 familiar / comfortable with Bayesian statistics.

\section{Results}

333 Developmental stage differences in immune markers

334 Spiders that reached maturity by the end of the rearing period on average hatched earlier than

335 those that only reached subadult stage $\left(\mathrm{t}_{31.6}=-4.38, \mathrm{P}<0.001\right)$, indicating that individuals

336 became adults because they had more time to develop rather than having much more rapid

337 development. Also, the Chi-squared test showed no significant difference in the number of adults

338 and subadults between mothers $\left(\mathrm{X}_{8}^{2}=4.90, \mathrm{P}=0.768\right)$. 
339 There was no significant difference in bacterial growth inhibition power between subadult and

340 adult spiders (Fig. 1a-b), and growth rate did not affect bacterial growth inhibition (Table 1).

341 Males showed marginally significantly lower values of bacterial growth inhibition than females

342 (Fig. 1b). Adults showed significantly lower cell wall lytic activity than subadults (Fig. 1c-d), but

343 there was no difference between sexes, and growth rate did not have significant effect on cell

344 wall lytic activity (Table 1). The estimated precision of the bacterial growth inhibition

345 measurements was quite high $\left(\mathrm{R}=0.87, \mathrm{HPD}_{\text {lower }}=0.71, \mathrm{HPD}_{\text {upper }}=0.93\right)$. Precision of cell wall

346 lytic activity measurements was moderately $\operatorname{good}\left(\mathrm{R}=0.63, \mathrm{HPD}_{\text {lower }}=0.39, \mathrm{HPD}_{\text {upper }}=0.80\right)$.

347 We found no significant random intercept- (random intercept covariance $=-0.06, \mathrm{HPD}_{\text {lower }}=$ -

$3480.22, \mathrm{HPD}_{\text {upper }}=0.13, \mathrm{P}_{\mathrm{MCMC}}=0.672$ ) or residual covariance (residual covariance $=0.004$,

$\left.349 \mathrm{HPD}_{\text {lower }}=-0.03, \mathrm{HPD}_{\text {upper }}=0.05, \mathrm{P}_{\mathrm{MCMC}}=0.560\right)$ between bacterial growth inhibition and cell

350 wall lytic activity.

351 Association between reproductive status, fecundity and immune markers

352 The interaction between season and reproductive status in bacterial growth inhibition power was

353 not significant (Coefficient: 0.429, $\mathrm{HPD}_{\text {lower }}=-0.298, \mathrm{HPD}_{\text {upper }}=1.121, \mathrm{P}_{\mathrm{MCMC}}=0.245$ ), and

354 mated females showed significantly lower levels of bacterial growth inhibition (Fig. 2a-b, Table

355 2). Females that were collected during spring showed significantly lower levels of bacterial

356 growth inhibition than females from late summer (Fig. 2) (Coefficient: -1.220, HPD $_{\text {lower }}=$ -

357 1.784, $\left.\mathrm{HPD}_{\text {upper }}=-0.681, \mathrm{P}_{\mathrm{MCMC}}<0.001\right)$.

358 The effect of interaction between reproductive status and season was significant on the cell wall

359 lytic activity (Coefficient: $\left.1.064, \mathrm{HPD}_{\text {lower }}=0.412, \mathrm{HPD}_{\text {upper }}=1.757, \mathrm{P}_{\mathrm{MCMC}}=0.004\right)$ : while

360 there was no significant difference in cell wall lytic activity between virgin and mated females

361 collected during spring (Coefficient: -0.216, $\mathrm{HPD}_{\text {lower }}=-0.621, \mathrm{HPD}_{\text {upper }}=0.219, \mathrm{P}_{\mathrm{MCMC}}=$

362 0.362), among the females collected in late summer mated specimens showed significantly lower

363 cell wall lytic activity than virgin females (Coefficient: $-0.859, \mathrm{HPD}_{\text {lower }}=-1.237, \mathrm{HPD}_{\text {upper }}=$ -

364 0.486, $\mathrm{P}_{\mathrm{MCMC}}<0.001$; Fig. 2c-d).

365 The estimated precision of both the bacterial growth inhibition $\left(\mathrm{R}=0.84, \mathrm{HPD}_{\text {lower }}=0.78\right.$,

$\left.366 \mathrm{HPD}_{\text {upper }}=0.88\right)$ and cell wall lytic activity measurements were high $\left(\mathrm{R}=0.84, \mathrm{HPD}_{\text {lower }}=0.77\right.$,

$367 \mathrm{HPD}_{\text {upper }}=0.88$ ). There was no significant random intercept (random intercept covariance $=$

$3680.009, \mathrm{HPD}_{\text {lower }}=-0.078, \mathrm{HPD}_{\text {upper }}=0.087, \mathrm{P}_{\mathrm{MCMC}}=0.918$ ) or residual covariance (residual 
369 covariance $=-0.007, \mathrm{HPD}_{\text {lower }}=-0.021, \mathrm{HPD}_{\text {upper }}=0.008, \mathrm{P}_{\mathrm{MCMC}}=0.297$ ) between bacterial

370 growth inhibition and cell wall lytic activity, indicating no measurable association between them.

371 In the linear regression model, neither of the interaction terms were significant (between

372 bacterial growth inhibition and season: Coefficient $=-2.564, \mathrm{SE}=3.213, \mathrm{t}=-0.80, \mathrm{P}=0.429$;

373 between cell wall lytic activity and season: Coefficient $=-0.699, \mathrm{SE}=2.773, \mathrm{t}=-0.25, \mathrm{P}=$

374 0.802), therefore we excluded them from the final model. Bacterial growth inhibition power

375 showed significant negative association with fecundity in mated females (Fig. 3a), but cell wall

376 lytic activity did not (Fig. 3b, Table 3). Also, females collected during spring were significantly

377 more fecund than late summer females (Table 3).

378 In the binomial regression model on bacterial growth inhibition the interaction between fecundity 379 and season was not significant (Coefficient $=0.102, \mathrm{SE}=0.085, \mathrm{t}=1.20, \mathrm{P}=0.229$ ), and season 380 did not significantly affect the probability of producing a measurable inhibition zone (Coefficient

$381=-2.503, \mathrm{SE}=2.834, \mathrm{t}=-0.88, \mathrm{P}=0.377)$. Fecundity was negatively associated with this

382 probability, meaning that samples from more fecund females were more likely to produce no

383 bacterial growth inhibition at all (Coefficient $=-0.148, \mathrm{SE}=0.067, \mathrm{t}=-2.20, \mathrm{P}=0.028$ ). In the

384 binomial regression model on cell wall lytic activity the interaction between fecundity and 385 seasonality was significant (Coefficient $=0.281, \mathrm{SE}=0.128, \mathrm{t}=2.20, \mathrm{P}=0.028$ ), showing that

386 fecundity negatively affected the probability of producing measurable clearing zones only among 387 late summer females (Coefficient $=-0.238, \mathrm{SE}=0.118, \mathrm{t}=-2.02, \mathrm{P}=0.044$ ). Probability of 388 producing measurable clearing zone was only marginally significantly lower in spring females 389 (Coefficient $=-5.595, \mathrm{SE}=2.986, \mathrm{t}=-1.87, \mathrm{P}=0.061)$.

390

\section{Discussion}

392 Subadults $P$. agrestis specimens had stronger lytic activity against bacterial cell wall compared 393 to adult individuals. This result indicates that tissue homogenate samples from subadult spiders 394 contained higher amount of lysozyme per unit body volume, than did samples from adults. This 395 is in accordance with our prediction based on life history theory, namely that in a semelparous 396 species one would expect to see relatively lower efficiency of somatic maintenance in adults 397 compared to subadults. We propose that this difference is likely due to a shift in resource 398 allocation patterns, altering the prioritization between somatic maintenance and reproduction. 
399 Subadults do not have fully developed, functional reproductive organs yet (Foelix, 2011), so

400 their reproductive tissues are likely to have lower demand of resource income in comparison to

401 adults. Mature individuals, however, have to invest resources into gonad development and

402 gamete production. Consequently, a higher proportion of the acquired energy and nutrients can

403 be assigned to somatic tissues and to elements of somatic maintenance in subadults, while these

404 limited resources will be partitioned into reproductive tissues and gamete production as well in

405 adults. Producing gametes has considerable costs (Hayward \& Gillooly, 2001; Edward \&

406 Chapman, 2011; Michalk \& Rittschof, 2011), so by paying the costs of reproduction, adults are

407 presumably able to assign fewer resources to somatic maintenance.

408 The decreased lytic activity in adults in comparison to subadults may be associated with lower

409 resource allocation into this particular element of immunity, which would be in accordance with

410 our predictions. In M. aeneus it was shown that out of 10 screened lysozymes 4 were expressed

411 in higher levels in juveniles in comparison to adults, although in the case of 3 lysozymes,

412 expression levels were higher in adults (Vogel et al., 2014). In another study on white shrimps

413 (Litopenaeus vannamei) it was found that expression level of the screened lysozyme was

414 elevated in most of (albeit not in the last few) post-larval stages compared to adults (Gollas-

415 Galvan et al., 2017), indicating a dynamic change in lysozyme availability, with a peak during

416 the subadult stages. Notably, energetic costs of reproduction were found to be negatively linked

417 to lytic activity in the carabid beetle Carabus lefebvrei, where mated individuals showed

418 dramatically decreased lytic activity in comparison to virgin individuals (Giglio et al., 2016),

419 showing that not only maturation, but reproduction too can deteriorate the efficiency of this

420 immune function. Indeed, we found that in mated females collected during late summer, bacterial

421 growth inhibition power and cell wall lytic activity were lower than in virgin females, indicating

422 that the cost of reproduction is relatively higher (or, at least, more pronounced) in late summer

423 females. Females from spring and late summer belong to two separate generations of different

424 life cycles (Kiss \& Samu, 2005; Rádai et al., 2017a), and it is not clear how external seasonal

425 conditions and the spiders' intrinsic physiological characteristics contribute to the observed

426 patterns. Albeit we acknowledge the potential importance of this aspect of the life cycle of $P$.

427 agrestis spiders, reconciling the mechanism behind this seasonal difference in lytic activity is

428 beyond the scope of this study. 
429 In past studies, immune measures in subadults were found to show comparable, or even higher 430 levels than in adults in a handful of invertebrate species. For example, although not assessed 431 explicitly, in the study of Vogelweith et al. (2017) earwig (Forficula auricularia) juveniles 432 seemed to have hemocyte concentrations in their hemolymph similar to that of adults, and 4th 433 instar (penultimate) larvae even had higher hemocyte counts than adults. Also, 4th instar larvae 434 appeared to have slightly higher total phenoloxidase activity compared to adult males, but not to 435 females. Piñera et al. (2013) found that 8th and 9th instar larvae of the cricket Acheta domesticus 436 had hemocyte loads and encapsulation efficiency similar to, or in some cases higher than, adults. 437 However, juveniles had considerably lower phenoloxidase activity compared to adults. In the 438 cricket Gryllus texenis males were shown to have lower phenoloxidase activity than nymphs, and 439 their phenoloxidase activity considerably declined with age after maturation (Adamo et al., 440 2001).

441 Surprisingly, subadults did not seem to differ from adults in bacterial growth inhibition power 442 against Micrococcus luteus. This result suggests no change in the overall availability of 443 antimicrobial peptides due to maturation. Considering studies similar to ours, however, it seems 444 unlikely that antimicrobial peptide levels do not change at all throughout the life cycle. For example, expression levels of antimicrobial peptides were shown to change over ontogeny in the pollen beetle Meligethes aeneus (Vogel et al., 2014). Notably, only some of the screened antimicrobial peptide transcripts were observed to decrease after maturation, indicating that not only the overall availability of these biomolecules might show ontogenetic stage-dependent shifts, but also the composition of them. How changes in the composition of available antimicrobial peptides affect the animals' capacity to overcome pathogen invasion, is a question to be considered in future studies. Notably, the absence of significant difference in bacterial growth inhibition between subadults and adults could be a result of depressed antimicrobial protein concentration in both tested life stages, in comparison to juveniles. Unfortunately, in the current study design we cannot confirm whether this is the case or not.

455 We saw similar patterns in males and females regarding the effect of maturation on the assessed immune markers. Although males showed somewhat lower capacity for bacterial growth inhibition compared to females, this difference was only marginally significant, and there was no sex difference in cell wall lytic capacity. While gamete production is expected to be more costly in females, our observations do not show stronger effect of maturation in females in either of the 
460 immune measures. In the past, costs of sperm production in males was thought to be relatively

461 "cheap", but recent studies show that males also pay considerable energetic costs for gamete

462 production and storage (Michalik \& Rittschof, 2011), which costs might have contributed to

463 similar energetic conflicts between the tested immune markers and reproductive investment

464 during maturation in the sexes. Notably, due to the low final sample sizes of data on the

465 laboratory reared spiders drawing general conclusions was made with caution, as some

466 ambiguities in our results may have resulted from the low sample size, such as the absence of

467 significant sex-differences in the immune measures, or their association with life stage.

468 Nevertheless, the similar decrease in lytic activity in both sexes might suggest that not only

469 gamete production, but maturation itself also has considerable energetic costs that might mask

470 sex-differences in the changes in immunity associated with the life stage transition.

471 While mated females collected in late summer showed a much more prominent decrease in cell

472 wall lytic activity than in bacterial growth inhibition, and subadults and adults only differed in

473 cell wall lytic activity, we found no significant linear association between cell wall lysis and

474 fecundity. It should be noted, however, that a considerable number of samples from mated

475 females failed to induce measurable clearing zones on the cell wall agar. Consequently, the

476 number of observations in which we could regress fecundity on non-zero values of cell wall lytic

477 activity was quite low, rendering it difficult to identify a credible linear association between

478 these variables. Based on the binomial models, females with higher fecundity were more likely

479 to have undetectable lytic activity, although this observation was significant only in late summer.

480 Bacterial growth inhibition showed no stage-differences, and was only slightly decreased in

481 mated females. Note, however, that bacterial growth inhibition showed considerable negative

482 correlation with fecundity, both in spring and late summer females. While this correlation was

483 not significant in the case of lytic activity, more fecund late summer females were still more

484 likely to exhibit zero cell wall lytic competence. Altogether, these observations seem to support

485 that physiological costs of production and storage of the wide variety of antimicrobial

486 biomolecules may interfere with elements of reproduction. Indeed, reproduction (and

487 reproductive effort) is often shown to be negatively associated with elements of

488 immunocompetence (Nordling et al., 1998; Schwenke et al., 2016).

489 We propose that lower adult capacity of bacterial cell wall lysis, and decreased capacity to

490 inhibit bacterial growth and to break down cell wall in mated females characterised by high 
491 fecundity, may be due to that adults have only one short time period for reproduction. As such,

492 the trade-off between immunity and fecundity might be expected to be quite substantial in 493 species that reproduce only once throughout their lifetime. The main argument for this is that

494 they have to invest as much as possible into the first reproduction in order to maximise

495 reproductive output, because in semelparous organisms there are no future reproductions, i.e. the

496 first reproduction is also the last. As such, this may lead to a "quasi-terminal investment" into

497 reproduction, in which an individual might take the risk of having some elements of

498 immunocompetence at a decreased efficiency duo to decreased investment into somatic

499 maintenance, for the prospect of increased reproductive success. The negative correlation

500 between bacterial growth inhibition power and fecundity, and the decreased capacity of

501 producing measurable bacterial growth inhibition and cell wall lysis in more fecund females

502 appear to support this hypothesis, as those females that "gave up" more capacity in the assessed

503 immune measures tended to have a larger number of offspring. Maximising reproductive output

504 through a terminal investment-like scenario would be expected to be favoured by natural

505 selection in environments where adult future mortality rate is high (assuming that this high

506 mortality is not due to pathogens), which is known to be characteristic to populations of

507 semelparous species (Goldstein et al., 2017; Sæther, 1988; Young, 2010).

508 Differences in expected pathogen diversity or prevalence were also proposed to drive the 509 evolution of life stage differences in immune function (Wilson-Rich et al., 2008; Shi \& Sun,

510 2010). We, however, find this proposition unlikely to be the main cause of the difference in lytic

511 activity between subadults and adults in P. agrestis, because they reside in the same habitat and

512 are quite the same in their foraging habits and preys (Nyfeller \& Benz, 1988; Samu \& Szinetár,

513 2002; personal observations of the authors).

514 Because both the maintenance of an efficient immune system and a higher rate of post-

515 embryonic development are considered to be costly, one might expect the presence of a negative

516 correlation between them (e.g. Modak et al., 2009; but see Rantala \& Roff, 2006). However, we

517 found no significant trend regarding the relationship between growth rate and bacterial growth

518 inhibition or cell wall lytic activity in the laboratory-reared spiders. Notably, ad libitum

519 availability of food might have mitigated the energetic conflict between these traits leading to the

520 observed results (Brzęk \& Konarzewski, 2007; Mangel \& Stamps, 2001). In a previous study we

521 have found a positive relationship between age at maturation and encapsulation efficiency in $P$. 
522 agrestis adults (Rádai et al., 2018a), meaning that individuals characterized by faster

523 development showed weaker encapsulation response. In the cricket Gryllus bimaculatus,

524 developmental time was found to be positively correlated with lytic activity of the hemolymph,

525 but was negatively associated with encapsulation rate (Rantala \& Roff, 2005).

526 The result that no significant relationship was found between bacterial growth inhibition power 527 and cell wall lytic activity either suggests that there is little, or no energetic conflict between

528 these two immune parameters, or that other, in physiological sense costly, traits obscure this

529 conflict between the two assessed elements of immunity. A potential energetic conflict may also

530 have been masked by the unrestricted food availability of the laboratory reared specimens. Also,

531 the absence of a positive association implies that individuals that invest relatively more in

532 bacterial growth inhibition are not necessarily able (or prone to) invest similarly high amount of

533 resources into lysozyme production (and vice versa). It should be noted, though, that while cell

534 wall lytic activity is mainly dependent on lysozymes, bacterial growth inhibition results from the 535 presence of many types of peptides and proteins, which lysozyme is also a part of. Hence, the

536 failure to detect a significant relationship between bacterial growth inhibition and cell wall lytic

537 activity may be due to the sheer number of biomolecules with a role in bacterial growth

538 inhibition that can have diverse associations with lysozymes, rendering it difficult to identify a

539 consistent association between them. It is also noteworthy that in the case of other elements of

540 immunity it is often found that there is no strict association between assessed immune parameters

541 (e.g. Fedorka et al., 2004; Gershman et al., 2010; Kortet et al., 2007; Piñera et al., 2013).

\section{Conclusions}

544 Overall, our results show that in a semelparous species adults are characterized by lower cell

545

546

547

548

549

550

551 wall lytic activity in comparison with subadults, but we found no evidence for subadults and adults to differ in their bacterial growth inhibition power. We argue that a likely explanation for relatively higher subadult lytic activity may be associated with an energetic conflict leading to a shift in prioritization between somatic and reproductive tissues in adults. This conflict is expected on the basis that adults of a semelparous species don't face the trade-off between current and future reproduction therefore maximal reproductive success may be achieved by allocating more resources into reproductive tissues, rather than in somatic maintenance and long- 
552 term survival. Also, bacterial growth inhibition was negatively associated with fecundity in 553 mated females, hinting at the presence of a trade-off between investments into reproduction 554 versus somatic maintenance. Indeed, among late summer specimens mated females had much

555 weaker bacterial growth inhibition power and cell wall lytic activity than virgins. Admittedly, in

556 future studies higher sample sizes and better balanced study designs will be needed in order to

557 clarify the remaining ambiguities of our results. Also, comparative studies on both semelparous

558 and iteroparous species would undoubtedly help to reconcile the role of reproductive strategies in

559 shaping trade-offs between key life history traits. We argue that $P$. agrestis would be an

560 excellent model organism to study both the intrinsic and extrinsic factors that might contribute to 561 these elements of life history evolution.

562

563 Acknowledgements

564 We are indebted to Dr. Tamás Emri for his aid in, and providing laboratory space for, the 565 conducted measurements, and to Dr. Attila Bácsi for his aid in long-term storage of our samples.

566 Also, we thank Dr. Ádám Kiss for his tools and help in photographing the spiders. We are

567 grateful to Dr. Jácint Tökölyi and three anonymous reviewers for their constructive comments on

568 the manuscript. The work/publication is supported by the EFOP-3.6.1-16-2016-00022 project. 


\section{References}

572 Adamo, S. A., Jensen, M., \& Younger, M. (2001). Changes in lifetime immunocompetence in

573 male and female Gryllus texensis (formerly G. integer): trade-offs between immunity and

574 reproduction. Animal Behaviour, 62(3), 417-425.

575 Ahtiainen, J. J., Alatalo, R. V., Kortet, R., \& Rantala, M. J. (2005). A trade-off between sexual

576 signalling and immune function in a natural population of the drumming wolf spider

577 Hygrolycosa rubrofasciata. Journal of evolutionary biology, 18(4), 985-991.

578 Bednaski, A. V., Trevisan-Silva, D., Matsubara, F. H., Boia-Ferreira, M., Olivério, M. M.,

579 Gremski, L. H., ... \& Toledo, M. S. (2015). Characterization of Brown spider (Loxosceles

580 intermedia) hemolymph: Cellular and biochemical analyses. Toxicon, 98, 62-74.

581 Biskupiak, J. E., Meyers, E., Gillum, A. M., Dean, L., Trejo, W. H., \& Kirsch, D. R. (1988).

582 Neoberninamycin, a new antibiotic produced by Micrococcus luteus. The Journal of Antibiotics, 583 41(5), 684-687. https://doi.org/10.7164/antibiotics.41.684

584 Brinkhof, M. W., Heeb, P., Kölliker, M., \& Richner, H. (1999). Immunocompetence of nestling

585 great tits in relation to rearing environment and parentage. Proceedings of the Royal Society of

586 London B: Biological Sciences, 266(1435), 2315-2322.

587 Brogden, K. A. (2005). Antimicrobial peptides: pore formers or metabolic inhibitors in bacteria?.

588 Nature reviews microbiology, 3(3), 238.

589 Brzęk, P., \& Konarzewski, M. (2007). Relationship between avian growth rate and immune

590 response depends on food availability. Journal of Experimental Biology, 210(13), 2361-2367.

591 Calsbeek, R., Bonneaud, C., \& Smith, T. B. (2008). Differential fitness effects of

592 immunocompetence and neighbourhood density in alternative female lizard morphs. Journal of

593 Animal Ecology, 77(1), 103-109.

594 Castella, G., Christe, P., \& Chapuisat, M. (2010). Covariation between colony social structure

595 and immune defences of workers in the ant Formica selysi. Insectes sociaux, 57(2), 233-238.

596 Cotter, S. C., Myatt, J. P., Benskin, C. M. H., \& Wilson, K. (2008). Selection for cuticular

597 melanism reveals immune function and life-history trade-offs in Spodoptera littoralis. Journal of

598 evolutionary biology, 21(6), 1744-1754.

599 Crino, O. L., Johnson, E. E., Blickley, J. L., Patricelli, G. L., \& Breuner, C. W. (2013). Effects of

600 experimentally elevated traffic noise on nestling white-crowned sparrow stress physiology,

601 immune function and life history. Journal of Experimental Biology, 216(11), 2055-2062.

602 DeBlock, M.; Stoks, R. (2008). Short-term larval food stress and associated compensatory 603 growth reduce adult immune function in a damselfly. Ecological Entomology, 33:796-801.

604 Edward, D. A.; Chapman, T. (2011). Mechanisms underlying reproductive trade-offs: Costs of

605 reproduction. In Flatt, T. and Heyland, A. (Eds.), Mechanisms of Life History Evolution (pp.

606 137-152). Oxford, Oxford University Press

607 Fedorka, K. M., Zuk, M., \& Mousseau, T. A. (2004). Immune suppression and the cost of

608 reproduction in the ground cricket, Allonemobius socius. Evolution, 58(11), 2478-2485.

609 Foelix, R. F. (2011). Biology of spiders. $3^{\text {rd }}$ edition. Oxford, NY: Oxford University Press. 
610 Gao, L., Zhang, J., Feng, W., Bao, N., Song, D., \& Zhu, B. C. (2005). Pharmacological

611 characterisation of spider antimicrobial peptides. Protein and peptide letters, 12(6), 507-511.

612 Gershman, S. N., Barnett, C. A., Pettinger, A. M., Weddle, C. B., Hunt, J., \& Sakaluk, S. K.

613 (2010). Give 'til it hurts: trade-offs between immunity and male reproductive effort in the

614 decorated cricket, Gryllodes sigillatus. Journal of evolutionary biology, 23(4), 829-839.

615 Giglio, A., \& Giulianini, P. G. (2013). Phenoloxidase activity among developmental stages and 616 pupal cell types of the ground beetle Carabus (Chaetocarabus) lefebvrei (Coleoptera, Carabidae).

617 Journal of insect physiology, 59(4), 466-474.

618 Giglio, A., Brandmayr, P., Cammarata, M., Cavaliere, F., Trapani, M., \& Giulianini, P. (2016).

619 Are immune responses gender-related in Carabus lefebvrei (Coleoptera: Carabidae)?.

620 Invertebrate Survival Journal, 13(13), 102-110

621 Gilbert, R., Karp, R. D., \& Uetz, G. W. (2016). Effects of juvenile infection on adult immunity

622 and secondary sexual characters in a wolf spider. Behavioral Ecology, 27(3), 946-954.

623 Goldstein, E. A., Merrick, M. J., \& Koprowski, J. L. (2017). Functional semelparity drives

624 population dynamics and endangers a peripheral population. Biological conservation, 205, 52-59

625 Gollas-Galvan, T., Cabanillas-Gámez, M., Hernández-López, J., Coronado-Molina, D., \&

626 Martínez-Porchas, M. (2017). Transcriptional expression of immune system genes in

627 Litopenaeus vannamei during ontogenetic development. Aquaculture Research, 48(3), 1110-

$628 \quad 1118$

629 Hadfield, J. D. (2010). MCMC methods for multi-response generalized linear mixed models: the 630 MCMCglmm R package. Journal of Statistical Software, 33(2), 1-22

631 Hadfield, J. (2018). MCMCglmm course notes. See http://cran. r-project.

$632 \mathrm{org} / \mathrm{web} /$ packages/MCMCglmm/vignettes/CourseNotes. pdf.

633 Harshman, L. G.; Zera, A. J. (2007). The cost of reproduction: the devil in the details. Trends in

634 Ecology and Evolution, 22(2):80-86

635 Hayward, A., \& Gillooly, J. F. (2011). The cost of sex: quantifying energetic investment in

636 gamete production by males and females. PLoS One, 6(1), e16557

637 Jacot, A.; Scheuber, H. Kurtz, J.; Brinkhof, M. W. G. (2005). Juvenile immune system activation

638 induces a costly upregulation of adult immunity in field crickets Gryllus campestris. Proceedings

639 of the Royal Society B, 272:63-69

640 Kiss, B. 2003. Autecology of the wolf spider Pardosa agrestis (Westring, 1861). PhD

641 dissertation, University of Veszprém, Hungary

642 Kiss, B., \& Samu, F. (2005). Life history adaptation to changeable agricultural habitats:

643 Developmental plasticity leads to cohort splitting in an agrobiont wolf spider. Environmental

644 entomology, 34(3), 619-626.

645 Kortet, R., Rantala, M. J., \& Hedrick, A. (2007). Boldness in anti-predator behaviour and 646 immune defence in field crickets. Evolutionary Ecology Research, 9(1), 185-197

647 Kriengwatana, B.; Wada, H.; Macmillan, A.; MacDougall-Shackleton, S. (2013). Juvenile

648 Nutritional Stress Affects Growth Rate, Adult Organ Mass, and Innate Immune Function in 
649 Zebra Finches (Taeniopygia guttata). Physiological and Biochemical Zoology: Ecological and 650 Evolutionary Approaches, 86(6):769-781

651 Kuhn-Nentwig, L.; Nentwig, W. (2013). The Immune System of Spiders. In Nentwig, W. (Ed.),

652 Spider Ecophysiology (pp. 81-91), Berlin, Springer-Verlag Berlin Heidelberg

653 Lawniczak, M. K., Barnes, A. I., Linklater, J. R., Boone, J. M., Wigby, S., \& Chapman, T.

654 (2007). Mating and immunity in invertebrates. Trends in Ecology \& Evolution, 22(1), 48-55.

655 Litman, R. M. (1968). A deoxyribonucleic acid polymerase from Micrococcus luteus

656 (Micrococcus lysodeikticus) isolated on deoxyribonucleic acid-cellulose. Journal of Biological

657 Chemistry, 243(23), 6222-6233.

658 Lochmiller, R. L.; Deerenberg, C. (2000). Trade-offs in evolutionary immunology: just what is

659 the cost of immunity? Oikos, 88:87-98.

660 Martin, L. B.; Weil, Z. M.; Nelson, R. J. (2007). Immune defense and reproductive pace of life in 661 Peromyscus mice. Ecology, 88:2516-2528.

662 Mangel, M., \& Stamps, J. (2001). Trade-offs between growth and mortality and the maintenance 663 of individual variation in growth. Evolutionary Ecology Research, 3(5).

664 McKean, K. A., \& Lazzaro, B. P. (2011). The costs of immunity and the evolution of 665 immunological defense mechanisms. Mechanisms of life history evolution, 299-310.

666 Meunier, J., Wong, J. W., Gómez, Y., Kuttler, S., Röllin, L., Stucki, D., \& Kölliker, M. (2012).

667 One clutch or two clutches? Fitness correlates of coexisting alternative female life-histories in

668 the European earwig. Evolutionary ecology, 26(3), 669-682.

669 Michalik, P., \& Rittschof, C. C. (2011). A comparative analysis of the morphology and evolution 670 of permanent sperm depletion in spiders. PLoS One, 6(1), e16014.

671 Modak, S. G., Satish, K. M., Mohan, J., Dey, S., Raghavendra, N., Shakarad, M., \& Joshi, A. 672 (2009). A possible tradeoff between developmental rate and pathogen resistance in Drosophila 673 melanogaster. Journal of genetics, 88(2), 253-256.

674 Nakazawa, M. (2018). fmsb: Functions for Medical Statistics Book with some Demographic

675 Data. R package version 0.6.3. https:/CRAN.R-project.org/package $=\mathrm{fmsb}$

676 Nordling, D., Andersson, M., Zohari, S., \& Lars, G. (1998). Reproductive effort reduces specific 677 immune response and parasite resistance. Proceedings of the Royal Society of London B:

678 Biological Sciences, 265(1403), 1291-1298.

679 Norris, K., \& Evans, M. R. (2000). Ecological immunology: life history trade-offs and immune 680 defense in birds. Behavioral Ecology, 11(1), 19-26.

681 Nyffeler, M., \& Benz, G. (1988). Feeding ecology and predatory importance of wolf spiders 682 (Pardosa spp.)(Araneae, Lycosidae) in winter wheat fields 1. Journal of Applied Entomology, 683 106(1-5), 123-134.

684 Owens, I. P., \& Wilson, K. (1999). Immunocompetence: a neglected life history trait or 685 conspicuous red herring?. Trends in Ecology \& Evolution, 14(5), 170-172.

686 Palacios, M. G., Cunnick, J. E., \& Bronikowski, A. M. (2013). Complex interplay of body 687 condition, life history, and prevailing environment shapes immune defenses of garter snakes in 688 the wild. Physiological and Biochemical Zoology, 86(5), 547-558. 
689 Park, Y., \& Stanley, D. (2015). Physiological trade-off between cellular immunity and flight

690 capability in the wing-dimorphic sand cricket, Gryllus firmus. Journal of Asia-Pacific

691 Entomology, 18(3), 553-559.

692 Piñera, A. V., Charles, H. M., Dinh, T. A., \& Killian, K. A. (2013). Maturation of the immune

693 system of the male house cricket, Acheta domesticus. Journal of insect physiology, 59(8), 752-

694760.

695 Rádai, Z., Kiss, B., \& Samu, F. (2017a). Effect of weather conditions on cohort splitting in a 696 wolf spider species. The Journal of Arachnology, 45(3), 444-447.

697 Rádai, Z., Kiss, B., \& Barta, Z. (2017b). Pace of life and behaviour: rapid development is linked

698 with increased activity and voracity in the wolf spider Pardosa agrestis. Animal Behaviour, 126, 699 145-151.

700 Rádai, Z., Németh, Z., \& Barta, Z. (2018a). Sex-dependent immune response in a semelparous

701 spider. The Science of Nature, 105(7-8), 39.

702 Rádai, Z., Popovici, O., Vas, Z., \& Fusu, L. (2018b). First record of the parasitoid Idris

703 flavicornis (Hymenoptera: Scelionidae) from eggs of the wolf spider Pardosa agrestis (Araneae:

704 Lycosidae). Folia Entomologica, 79, 101-106.

705 Rantala, M. J., \& Roff, D. A. (2005). An analysis of trade-offs in immune function, body size

706 and development time in the Mediterranean Field Cricket, Gryllus bimaculatus. Functional

707 Ecology, 19(2), 323-330.

708 Rantala, M. J., \& Roff, D. A. (2006). Analysis of the importance of genotypic variation, 709 metabolic rate, morphology, sex and development time on immune function in the cricket,

710 Gryllus firmus. Journal of evolutionary biology, 19(3), 834-843.

711 Ricklefs, R. E.; Wikelski, M. (2002). The physiology/life-history nexus. Trends in Ecology and

712 Evolution, 17(10):462-468.

713 Rolff, J. (2002). Bateman's principle and immunity. Proceedings of the Royal Society of London

714 B: Biological Sciences, 269(1493), 867-872.

715 Sadd, B. M.; Schmid-Hempel, P. (2009). Perspective: Principles of ecological immunology.

716 Evolutionary Applications, 2(1):113-121.

717 Sæther, B. E. (1988). Pattern of covariation between life-history traits of European birds. Nature, 718 331(6157), 616.

719 Samu, F., \& Szinetár, C. (2002). On the nature of agrobiont spiders. Journal of Arachnology, $72030(2), 389-402$.

721 Schneider, C. A., Rasband, W. S., \& Eliceiri, K. W. (2012). NIH Image to ImageJ: 25 years of 722 image analysis. Nature methods, 9(7), 671-675.

723 Schwenke, R. A., Lazzaro, B. P., \& Wolfner, M. F. (2016). Reproduction-immunity trade-offs in 724 insects. Annual Review of Entomology, 61, 239-256.

725 Sharon, N. (1967). The chemical structure of lysozyme substrates and their cleavage by the 726 enzyme. Proc. R. Soc. Lond. B, 167(1009), 402-415 
727 Sheldon, B. C.; Verhulst, S. (1996). Ecological immunology: costly parasite defences and trade728 offs in evolutionary ecology. Trends in Ecology and Evolution, 11(8):317-321

729 Shi, Z. H., \& Sun, J. H. (2010). Immunocompetence of the red turpentine beetle, Dendroctonus

730 valens LeConte (Coleoptera: Curculionidae, Scolytinae): variation between developmental stages

731 and sexes in populations in China. Journal of Insect Physiology, 56(11), 1696-1701

732 Sims, G. K., Sommers, L. E., \& Konopka, A. (1986). Degradation of Pyridine by Micrococcus

733 luteus Isolated from Soil. Appl. Environ. Microbiol., 51(5), 963-968

734 Stoehr, A. M., \& Kokko, H. (2006). Sexual dimorphism in immunocompetence: what does life-

735 history theory predict?. Behavioral Ecology, 17(5), 751-756

736 Team, R. C. (2014). R: A language and environment for statistical computing. Vienna, Austria:

737 R Foundation for Statistical Computing; 2014

738 Vincent, C. M., \& Gwynne, D. T. (2014). Sex-biased immunity is driven by relative differences

739 in reproductive investment. Proceedings of the Royal Society B: Biological Sciences, 281(1790),

74020140333.

741 Viney, M. E., Riley, E. M., \& Buchanan, K. L. (2005). Optimal immune responses:

742 immunocompetence revisited. Trends in Ecology \& Evolution, 20(12), 665-669

743 Vogel, H., Badapanda, C., Knorr, E., \& Vilcinskas, A. (2014). RNA-sequencing analysis reveals

744 abundant developmental stage-specific and immunity-related genes in the pollen beetle

745 Meligethes aeneus. Insect molecular biology, 23(1), 98-112

746 Vogelweith, F., Körner, M., Foitzik, S., \& Meunier, J. (2017). Age, pathogen exposure, but not

747 maternal care shape offspring immunity in an insect with facultative family life. BMC

748 evolutionary biology, 17(1), 69 .

749 Westring, N. (1861). Göteborgs Kungliga Vetenskaps och Vitterhets Samhälles Handlingar.

750 Araneae sveciae, 7:1-615

751 Wilson, A. J., Reale, D., Clements, M. N., Morrissey, M. M., Postma, E., Walling, C. A., ... \&

752 Nussey, D. H. (2010). An ecologist's guide to the animal model. Journal of Animal Ecology,

753 79(1), 13-26.

754 Wilson-Rich, N., Dres, S. T., \& Starks, P. T. (2008). The ontogeny of immunity: development of

755 innate immune strength in the honey bee (Apis mellifera). Journal of Insect Physiology, 54(10),

756 1392-1399.

757 Young, T. P. (2010). Semelparity and Iteroparity. Nature Education Knowledge 3(10):2 


\section{Figure 1}

Immune function across ontogenetic stages.

Box plot visualization of bacterial growth inhibition $(A, B)$ and cell wall lytic activity $(C, D)$ of females $(A, C)$ and males $(B, D)$ of laboratory-reared spiders $(N=38)$. Whiskers visualize minimum and maximum ranges, within which boxes represent interquartile range between first and third quartiles; horizontal solid lines show median of the given value distribution; individual circles show outlier values. Asterisks mark significant effect or difference $(P \leq$ 0.05). 
Females

Males
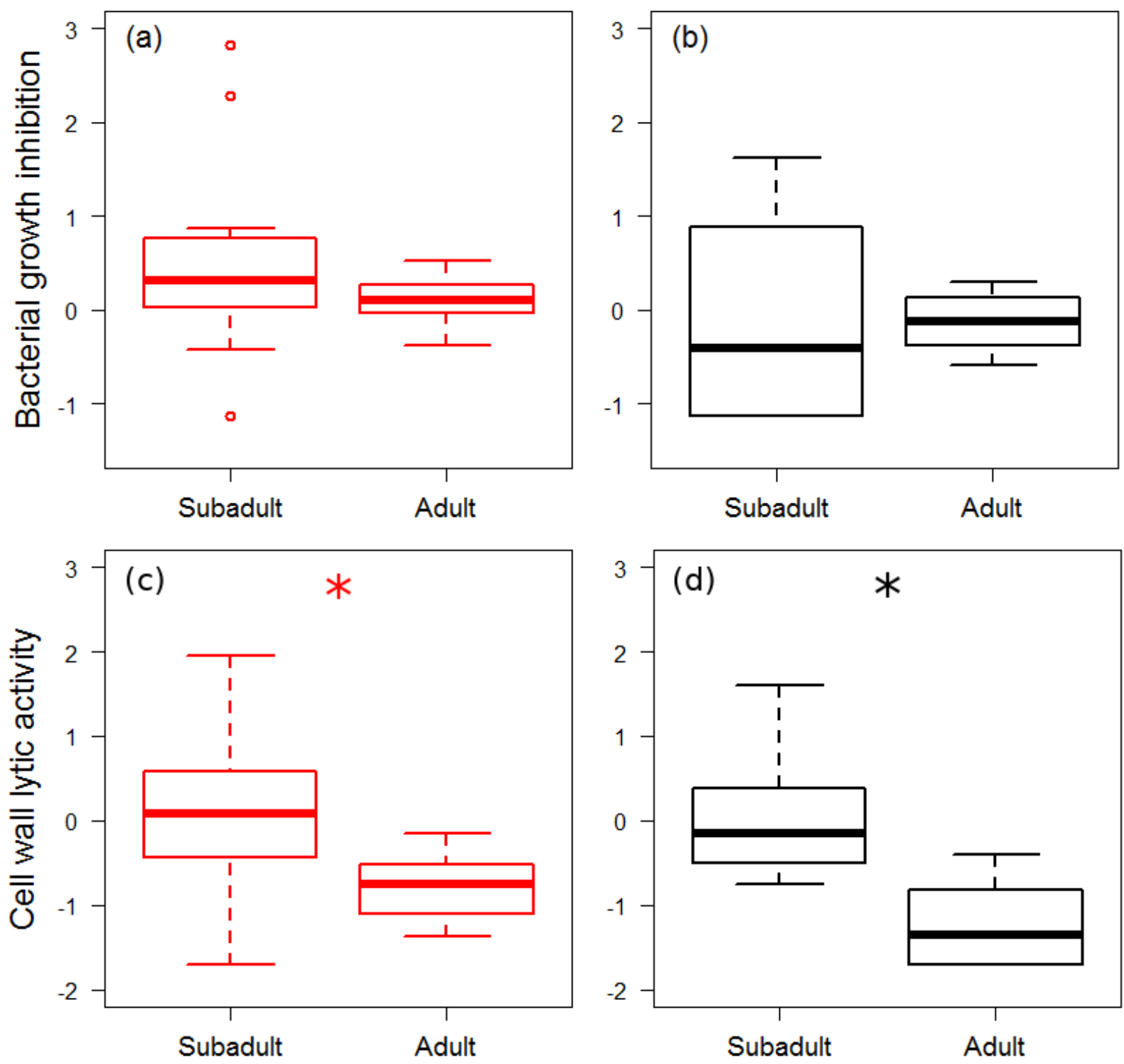


\section{Figure 2}

Immune function in females.

Box plot visualization of bacterial growth inhibition power (A, B) and cell wall lytic activity (C, D) of virgin versus mated females, collected during spring $(a, c ; n=108)$ and late summer ( $B, D ; n=51$ ). Whiskers visualize minimum and maximum ranges, within which boxes represent interquartile range between first and third quartiles; horizontal solid lines show median of the given value distribution; individual circles show outlier values. Asterisks mark significant effect or difference $(P \leq 0.05)$. 
Spring

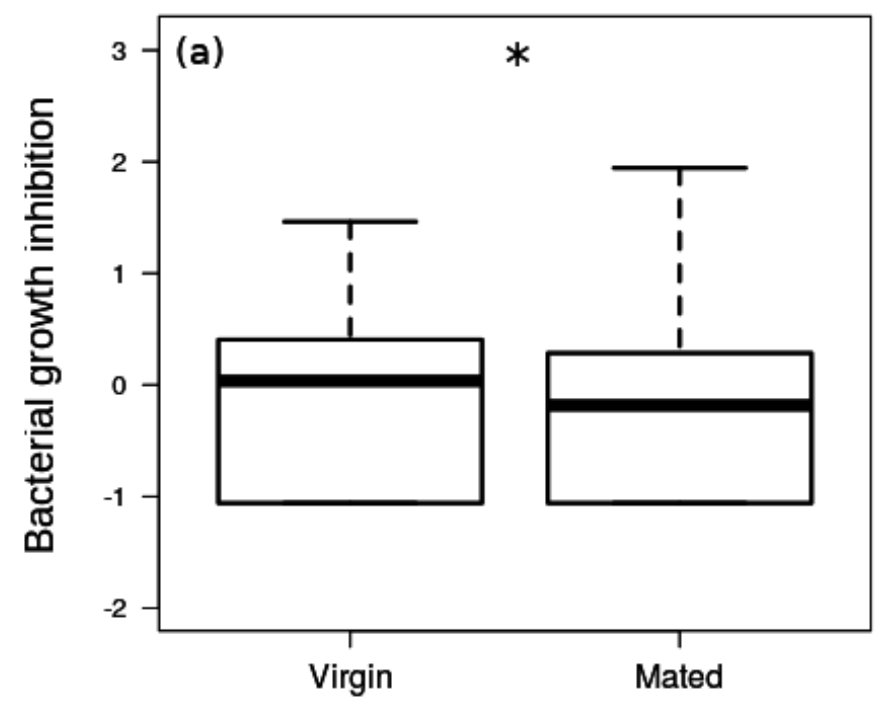

Spring

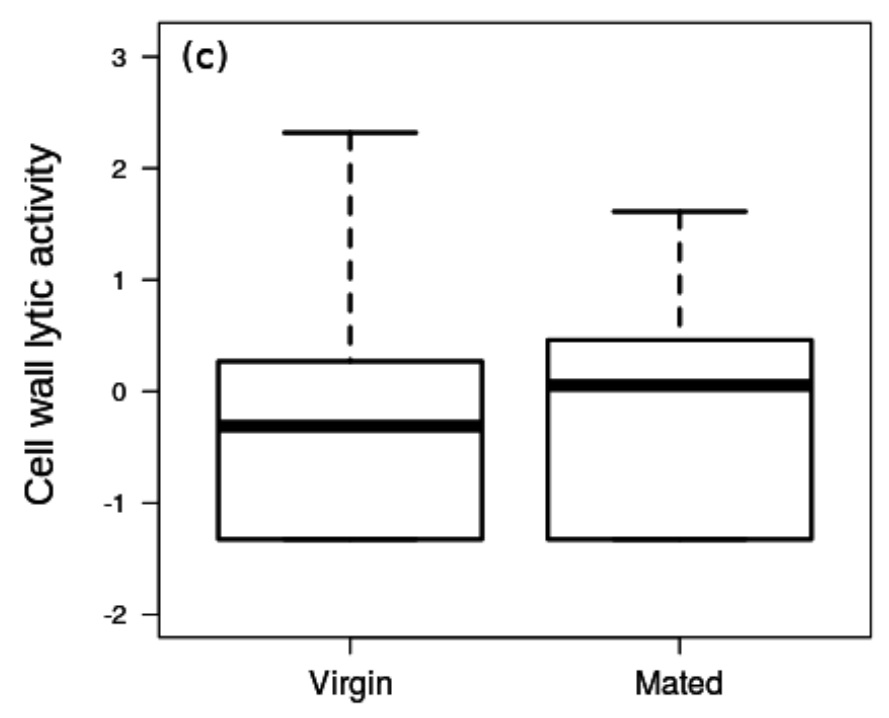

Late summer

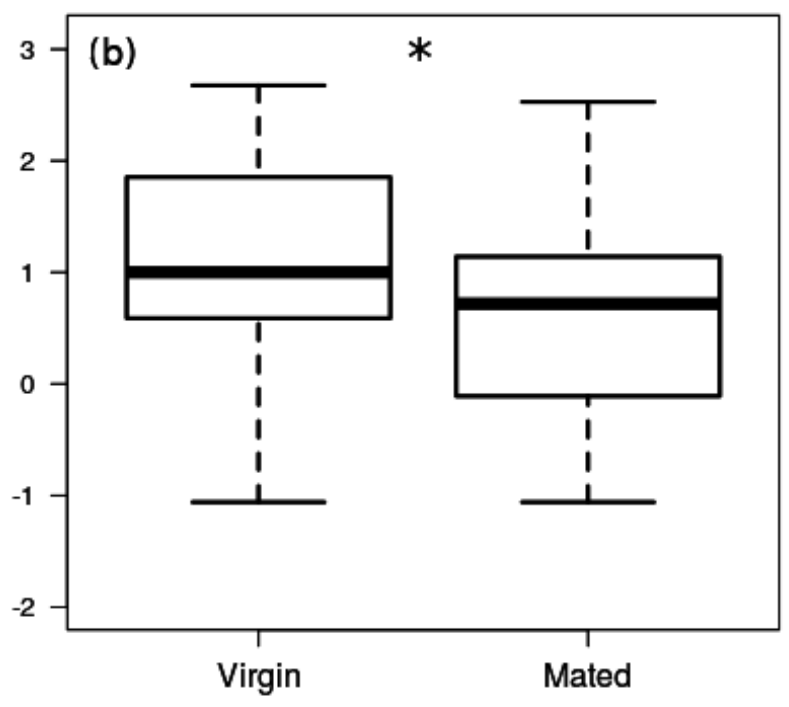

Late summer

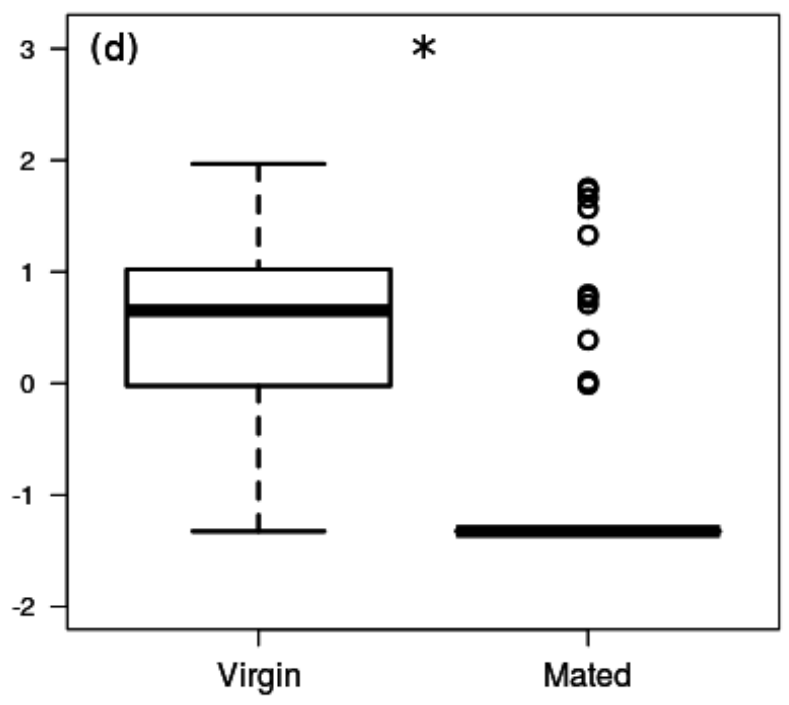


Figure 3

Immune function and fecundity.

Association of bacterial growth inhibition (A) and cell wall lytic activity (B) with fecundity in mated females collected in spring (black circles; $n=25$ ) and autumn (blue circles; $n=28$ ). Lines show regression lines from the fitted linear model: solid and dashed lines represent significant $(P \leq 0.05)$ and non-significant $(P>0.05)$ associations, respectively.
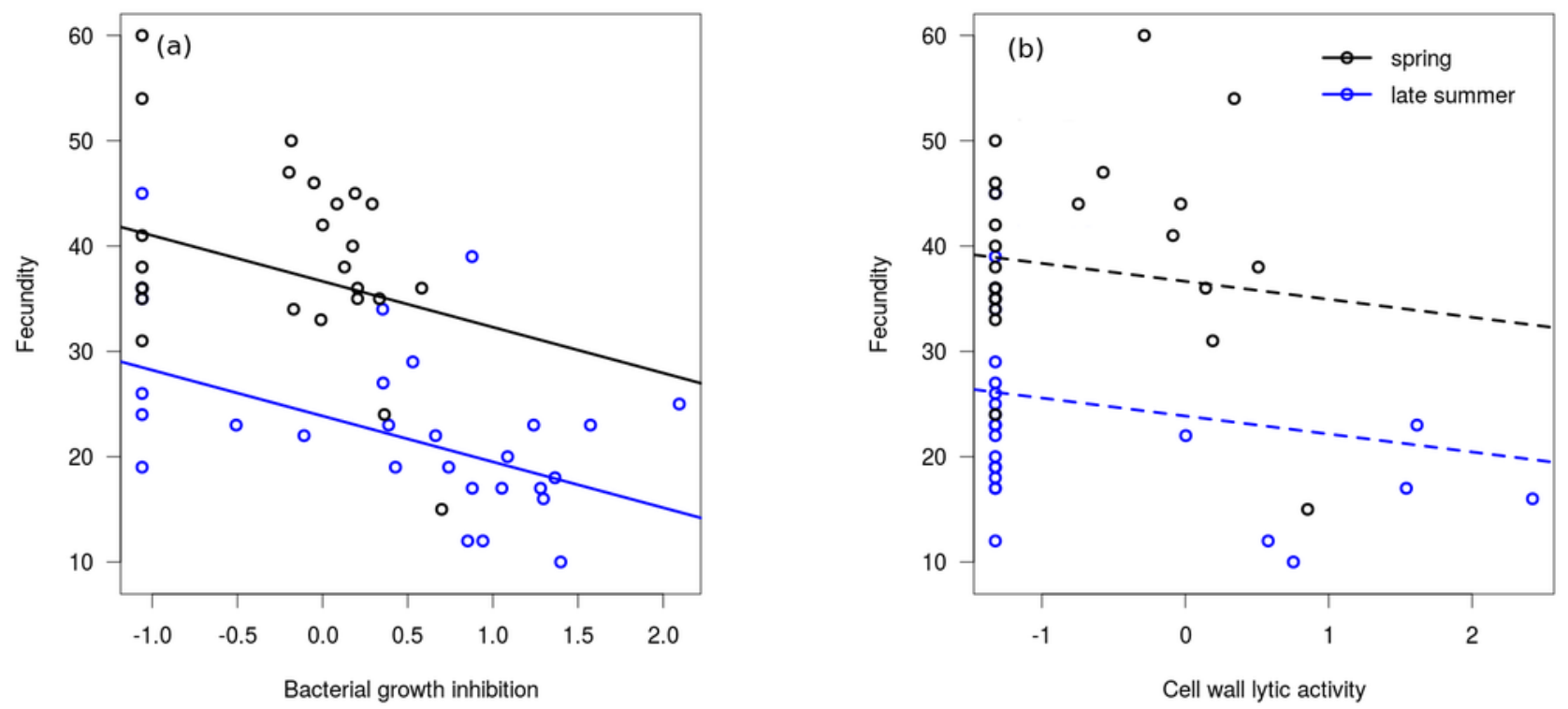


\section{Table $\mathbf{1}$ (on next page)}

Fixed parameter estimates from the multi-response model on the effect of developmental stage and sex on immune markers.

For categorical predictors (ontogenetic stage and sex) the contrast parameter is presented (i.e., average difference between two contrasted groups; subadult (S) to adult (A) in Stage, female (F) to male (M) in Sex). Asterisks mark significant effect or difference $(P \leq 0.05)$. 
1

\begin{tabular}{|c|l|c|c|c|c|}
\hline Response & Predictors & Coefficient & HPD $_{\text {lower }}$ & HPD $_{\text {upper }}$ & P $_{\text {MCMC }}$ \\
\hline \multirow{2}{*}{$\begin{array}{c}\text { Bacterial } \\
\text { growth } \\
\text { inhibition }\end{array}$} & Stage (S - A) & 0.27 & -0.30 & 0.86 & 0.304 \\
\cline { 2 - 6 } & Sex (F - M) & -0.50 & -1.03 & 0.03 & 0.067 \\
\cline { 2 - 6 } & Growth rate & 0.71 & -5.23 & 6.27 & 0.790 \\
\hline \multirow{2}{*}{$\begin{array}{c}\text { Cell wall lytic } \\
\text { activity }\end{array}$} & Stage (S - A) & 1.04 & 0.57 & 1.60 & $<0.001^{*}$ \\
\cline { 2 - 6 } & Sex (F - M) & -0.17 & -0.66 & 0.33 & 0.489 \\
\cline { 2 - 6 } & Growth rate & 1.46 & -4.41 & 7.12 & 0.620 \\
\hline
\end{tabular}

2 


\section{Table 2 (on next page)}

Contrasts acquired from the multi-response model on the effect of reproductive status and season on females' immune markers.

In order to make results easier to comprehend and interpret, contrasts for the given groupinteractions are presented, instead of individual parameter estimates directly from the fitted model. Asterisks mark significant difference $(P \leq 0.05)$. 


\begin{tabular}{|c|c|c|c|c|c|}
\hline Response & Contrast & Coefficient & HPD $_{\text {lower }}$ & HPD $_{\text {upper }}$ & P $_{\text {MCMC }}$ \\
\hline $\begin{array}{c}\text { Bacterial } \\
\text { growth } \\
\text { inhibition }\end{array}$ & $\begin{array}{c}\text { Spring: } \\
\text { virgin - mated }\end{array}$ & 0.51 & 0.11 & 1.22 & $0.030^{*}$ \\
\cline { 2 - 6 } & $\begin{array}{c}\text { Late summer: } \\
\text { virgin - mated }\end{array}$ & 0.60 & 0.13 & 1.24 & $0.019^{*}$ \\
\hline \multirow{2}{*}{$\begin{array}{c}\text { Sell wall lytic } \\
\text { activity }\end{array}$} & $\begin{array}{c}\text { Spring: } \\
\text { virgin - mated }\end{array}$ & -0.16 & -0.52 & 0.45 & 0.759 \\
\cline { 2 - 6 } & $\begin{array}{c}\text { Late summer: } \\
\text { virgin - mated }\end{array}$ & 1.24 & 0.64 & 1.88 & $<0.001 *$ \\
\hline
\end{tabular}

2

3 


\section{Table 3(on next page)}

Fixed parameter estimates from the linear regression model on the association between immune markers and season with fecundity in mated females.

For the predictor variable Season the contrast coefficient is given, representing the

difference of spring specimens from late summer specimens. Asterisks mark significant effect $(P \leq 0.05)$. 
1

\begin{tabular}{|l|c|c|c|c|}
\hline \multicolumn{1}{|c|}{ Predictors } & Coefficient & SE & t value & P \\
\hline Bacterial growth inhibition & -4.15 & 1.31 & -3.16 & $0.003^{*}$ \\
\hline Cell wall lytic activity & -1.67 & 1.15 & -1.45 & 0.153 \\
\hline Season (spring) & 12.79 & 2.36 & 5.41 & $<0.001^{*}$ \\
\hline
\end{tabular}

2

3 